\title{
IN VITRO ANTICANCER POTENTIAL OF BIOSYNTHESIZED ZINC OXIDE NANOPARTICLES FROM THE SEAWEED TURBINARIA CONOIDES
}

\section{KHOUSHIKA RAAJSHREE R, BRINDHA DURAIRAJ*}

Department of Biochemistry, PSG College of Arts \& Science, Coimbatore, Tamil Nadu, India. Email: brindhavenkatesh6@gmail.com

Received: 25 August 2017, Revised and Accepted: 22 January 2018

ABSTRACT

Objective: The objective of this study is to investigate the anticancer potential of zinc oxide nanoparticles (ZnO-NPs) and hydroethanolic extract of Turbinaria conoides (HETC) against Dalton's lymphoma ascites (DLA) cell line.

Methods: Nanoparticles were synthesized from the HETC. An ultraviolet-visible spectrophotometric analysis was performed to confirm the formation of ZnO-NPs. Size, morphology, and elemental composition of ZnO-NPs were also analyzed using scanning electron microscope-energy dispersive X-ray diffraction. The cytotoxic activity of ZnO-NPs and HETC was evaluated by 3-(4,5-dimethythiazol-. 2-yl)-2,5-diphenyltetrazolium bromide (MTT) and trypan blue dye exclusion assays on DLA cells. The apoptosis inducing the effect was observed through acridine orange staining method (AO and EB) and DNA ladder assay.

Results: The results of in vitro cytotoxic studies by MTT and trypan blue dye exclusion assays on DLA cell line in the presence of ZnO-NPs showed an $\mathrm{IC}_{50}$ value of 23.13 and $25.81 \mu \mathrm{g} / \mathrm{ml}$, respectively. The DNA ladder assay and AO/EB staining clearly demonstrated that the ZnO-NPs at $50 \mu \mathrm{g} / \mathrm{ml}$ concentration induced a maximum apoptosis in DLA cells when compared with HETC.

Conclusion: In the present study, the cytotoxic and apoptotic inducing effect of the synthesized ZnO-NPs and HETC were assessed, and it was found that ZnO-NPs possessed potent anticancer effect against DLA cells.

Keywords: Dalton's lymphoma ascites, Turbinaria Conoides, Apoptosis.

(C) 2018 The Authors. Published by Innovare Academic Sciences Pvt Ltd. This is an open access article under the CC BY license (http://creativecommons. org/licenses/by/4. 0/) DOI: http://dx.doi.org/10.22159/ajpcr.2018.v11i5.22224

\section{INTRODUCTION}

Nanobiotechnology, an emerging field of nanoscience, utilizes nano-based systems for various biomedical applications. This rapidly developing field of nanoscience has raised the possibility of using therapeutic nanoparticles in the diagnosis and treatment of human cancers. The nanoscale level of detection and treatment has advantages such as stability, extended shelf life, limited dose frequency, and high specificity [1]. Hence, nanocarriers have recently emerged as attractive candidates for drug delivery due to their efficacy and limited toxicity. Inorganic nanoparticles, notably, metal nanoparticles have raised much interest in research for its material properties, availability, capability, specific targeting, and sustained release [2]. They are most promising for their long-term use in medicine and have much attraction for potential applications in cancers [3].

Cancer is an abnormal type of tissue growth in which the cells exhibit an uncontrolled division, relatively in an autonomous fashion, leading to a progressive increase in the number of dividing cells [4]. It is a major public health problem worldwide and is the second leading cause of death in the world [5,6]. Cancer comprises more than 100 types of malignancy. Lymphoma is a disease of the lymphocytes (a type of white blood cell involved in immune responses) and the lymphatic system, which includes the spleen, thymus, and liver, as well as other lymphatic tissues. Dalton's lymphoma ascites (DLA) is a transplantable, poorly differentiated malignant tumor which appeared originally as lymphocytes in the mouse. It grows as both solid and ascitic forms [4].

Over the past few decades, there has been increased interest by pharmaceutical industries to discover the new drugs from the ethnobotanicals to provide new and alternative drugs to synthetic drugs for the treatment of dreadful diseases [7]. Marine algae are one of the natural resources in the marine ecosystem. They contain various biologically active substances which serve as a component for nutraceutical and pharmaceutical industry [8]. Turbinaria conoides belongs to the family of Sargassaceae. It produces a great variety of secondary metabolites having a broad spectrum of biological activities. Hence, the present study was aimed to evaluate the cytotoxic and apoptotic effect of the synthesized zinc oxide nanoparticles (ZnO-NPs) and hydroethanolic extract of T. conoides (HETC) against DLA cell line.

\section{METHODS}

Collection and preparation of seaweed

The brown seaweed, T. conoides, was collected from Mandapam coastal region, Gulf of Mannar, Southeast coast of India. The algal samples were washed thoroughly with running tap water followed by distilled water to remove adhering salts and associated biota. The washed samples were dried under shade at room temperature for a week. The dried materials were ground to fine powder using mixer grinder and stored in an airtight container for further analysis.

\section{Preparation of algal extract}

The crude algal extract (CAE) was prepared by adding $10 \mathrm{~g}$ of algal powder into $100 \mathrm{ml}$ of $50 \%$ ethanol and kept in the rotatory shaker for $24 \mathrm{~h}$, filtered, collected the solvent, and was used for further analysis.

\section{Green synthesis of ZnO-NPs from CAE}

$20 \mathrm{ml}$ of the CAE was heated at $50^{\circ} \mathrm{C}$ for $10 \mathrm{~min}$, and $50 \mathrm{ml}$ of $91 \mathrm{mM}$ of zinc acetate solution ( $1 \mathrm{~g}$ of zinc acetate was dissolved in $50 \mathrm{ml}$ of distilled water) was added dropwise. This was then placed on a magnetic stirrer for $2 \mathrm{~h}$. Then, the precipitate was collected by centrifugation at $16,000 \mathrm{rpm}$ for $10 \mathrm{~min}$ at $4^{\circ} \mathrm{C}$. The pale white precipitate was then taken out and washed with distilled water followed by ethanol to get free of the impurities. The $\mathrm{ZnO}$-NPs were obtained after drying at $60^{\circ} \mathrm{C}$ in an oven overnight, and the sample was stored for further studies. 
Characterization of ZnO-NPs

The obtained $\mathrm{ZnO}$-NPs were measured for its maximum absorbance using UV-visible spectrophotometry. The optical property of ZnO-NPs was determined through ultraviolet and visible absorption spectroscopy in the range of 280-420 $\mathrm{nm}$. External morphology, i.e. the shape of the nanoparticles was characterized by scanning electron microscope (SEM). Elemental analysis was obtained from energy dispersive X-ray diffraction (EDX), which was attached with SEM

Anticancer potential of the synthesized nanoparticles and the algal extract

The cytotoxic activity of ZnO-NPs and HETC was evaluated by 3-(4,5-dimethythiazol-. 2-yl)-2,5-diphenyl tetrazolium bromide (MTT) and trypan blue dye exclusion assays on DLA cells. The apoptosis inducing the effect was observed through acridine orange-ethidium bromide dual staining method (AO/EB) and DNA fragmentation assay.

\section{Determination of cytotoxicity by MTT assay [9]}

DLA cells aspirated from DLA bearing mice were adjusted to a concentration of $1 \times 10^{6}$ cells $/ \mathrm{ml}$, plated onto 96 -well flat bottom culture plates, and treated with various concentrations of $\mathrm{ZnO}-\mathrm{NPs}$ and HETC. Incubated for $24 \mathrm{~h}$ at $37^{\circ} \mathrm{C}$ in a $5 \% \mathrm{CO}_{2}$ incubator and added $10 \mathrm{ml}$ of MTT to each well which was further incubated for $4 \mathrm{~h}$ at $37^{\circ} \mathrm{C}$. The formazan was dissolved in $100 \mathrm{ml}$ of dissolving buffer and the absorbance was read at $595 \mathrm{~nm}$ and the percentage cytotoxicity was calculated.

Determination of cytotoxicity by trypan blue dye exclusion technique [10]

For the assay, DLA cells aspirated from DLA-bearing mice were adjusted to a concentration of $1 \times 10^{6}$ cells in $0.1 \mathrm{ml}$ phosphate-buffered saline (PBS) (pH 7.4). To about $0.8 \mathrm{ml}$ of PBS, add $0.1 \mathrm{ml}$ of cell suspension containing $1 \times 10^{6}$ cells and treated with different concentrations of $\mathrm{ZnO}$ NPs and HETC. Incubated for $3 \mathrm{~h}$ at $37^{\circ} \mathrm{C}$ and added $0.1 \mathrm{ml}$ trypan blue dye. Applied a drop of trypan blue-cell mixture to a hemocytometer, and the stained (non-viable) and unstained (viable) cells were counted separately under a microscopic field. The percentage cytotoxicity was calculated.

\section{DNA ladder assay}

The induction of apoptosis was studied by DNA ladder assay [11]. $1 \times 10^{6}$ DLA cells were lysed in $250 \mu$ lysis buffer containing $50 \mathrm{mM}$ Tris $\mathrm{HCl}, \mathrm{pH}$ 8.0, $10 \mathrm{mM}$ ethylenediaminetetraacetic acid, $0.1 \mathrm{M} \mathrm{NaCl}$, and $0.5 \%$ sodium dodecyl sulfate. The lysate was incubated with $0.5 \mathrm{mg} / \mathrm{ml}$ RNase $\mathrm{A}$ at $37^{\circ} \mathrm{C}$ for $1 \mathrm{~h}$, and then with $0.2 \mathrm{mg} / \mathrm{ml}$ proteinase $\mathrm{K}$ at $50^{\circ} \mathrm{C}$ overnight. Phenol extraction of this mixture was carried out, and DNA in the aqueous phase was precipitated by $25 \mu \mathrm{l}(1 / 10$ volume) of 7.5 $\mathrm{M}$ ammonium acetate and $250 \mu \mathrm{l}(1 / 1$ volume $)$ isopropanol. DNA electrophoresis was performed on a $1 \%$ agarose gel containing $1 \mu \mathrm{g} / \mathrm{ml}$ ethidium bromide at $70 \mathrm{~V}$, and the DNA fragments were visualized by exposing the gel to ultraviolet light, followed by photography.

Detection of apoptotic morphological changes by AO/EB dual staining method

To investigate the cytotoxicity induced by apoptosis, AO and EB dual staining method was performed [12]. DLA cells were isolated from DLA bearing mouse and washed with PBS. $1 \times 10^{6}$ cells $/ \mathrm{ml}$ were treated with $50 \mu \mathrm{g} / \mathrm{ml}$ of $\mathrm{ZnO}$-NPs and HETC for $24 \mathrm{~h}$ at $37^{\circ} \mathrm{C}$, and $5 \% \mathrm{CO}_{2}$ level was maintained. After the incubation, cells were washed in PBS. Subsequently, the cells were stained with $20 \mathrm{l} \mathrm{EB}(100 \mathrm{~g} / \mathrm{ml})$ and $20 \mathrm{l}$ AO $(100 \mathrm{~g} / \mathrm{ml})$ in a ratio of 1:1. After washing, the cells were resuspended in PBS. The cells were then examined on a slide under a fluorescence microscope, and the images were captured.

\section{RESULTS AND DISCUSSIONS}

Biosynthesis of ZnO-NPs using Brown seaweed

ZnO-NPs were synthesized from the CAE of T. conoides by the green method, which is more reliable and less toxic when compared with chemical synthesis. The formation of pale-white color within $3 \mathrm{~h}$ of preparation indicated the synthesis of $\mathrm{ZnO}$ nanoparticles.
UV-visible spectral analysis

UV-visible spectral analysis recorded the optical absorption spectra of the samples when the size of the particle is reduced to the nanoscale. Fig. 1 shows the UV-visible absorption spectrum of ZnO-NPs. The absorption spectrum was recorded for the sample in the range of 280-420 nm. The spectrum showed the absorbance peak at $370 \mathrm{~nm}$ corresponding to the characteristic band of ZnO-NPs. The UV-visible spectrum showed the absorbance peak at $340 \mathrm{~nm}$ corresponding to the characteristic band of ZnO-NPs [13].

\section{SEM analysis}

The morphology of the synthesized nanoparticles was examined using SEM. Fig. 2a and b reveals the surface morphology of the synthesized ZnONPs under different magnifications. The SEM image showed that most of the nanoparticles are spherical with a diameter ranging from 70 to $120 \mathrm{~nm}$.

\section{EDX analysis}

The EDX study was carried out for the synthesized $\mathrm{ZnO}$-NPs to elucidate the elemental composition. EDX confirms the presence of zinc and oxygen signals of $\mathrm{ZnO}$-NPs as depicted in Fig. 3.

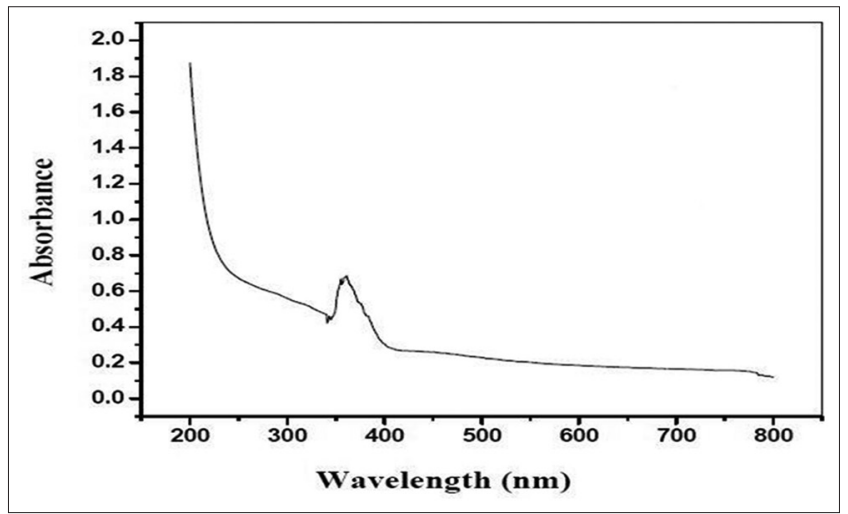

Fig. 1: UV-visible spectrum of synthesized zinc oxide nanoparticles
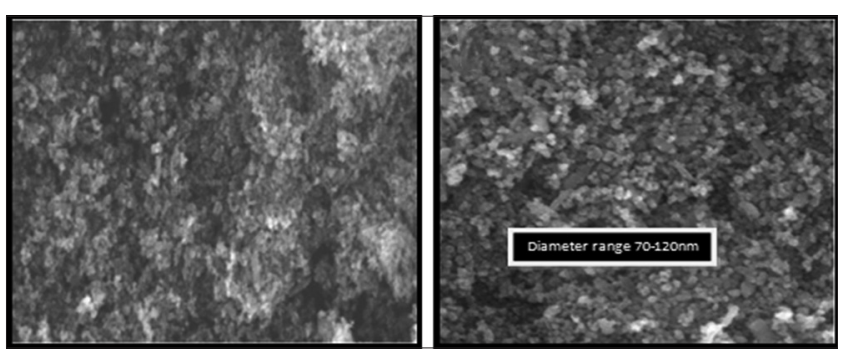

Fig. 2: Scanning electron microscope image of the synthesized zinc oxide nanoparticles

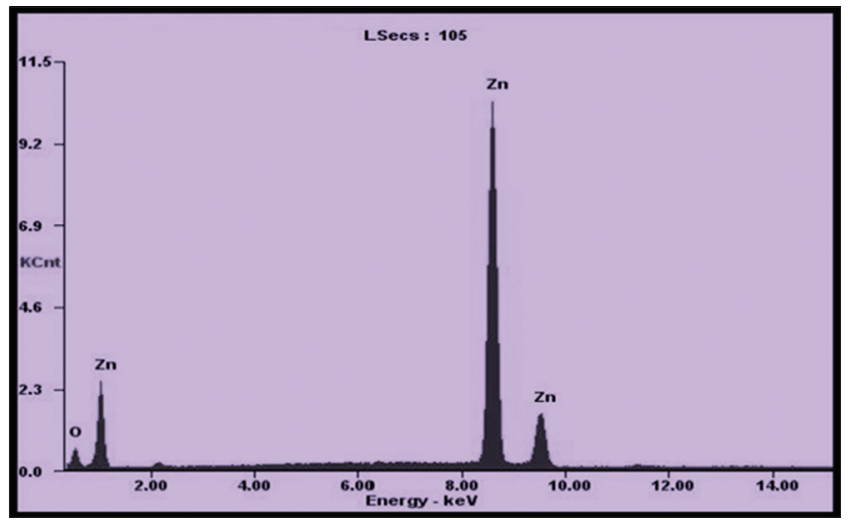

Fig. 3: Energy dispersive X-ray diffraction spectrum of synthesized zinc oxide nanoparticles 
The results revealed that the peaks correspond to the optical absorption of the produced nanoparticle. The elemental analysis of the nanoparticle yielded $77.32 \%$ zinc and $22.68 \%$ oxygen which proved that the produced nanoparticle is in its highest purified form.

The observed results are in good rapport with the SEM-EDX analysis of ZnO nanoparticles synthesized using Spathodea campanulata [14].

Anticancer potential of the synthesized nanoparticles and the hydroethanolic extract

Determination of cytotoxicity by MTT assay

Cytotoxic effect on DLA cell line was investigated by MTT assay, and the results were shown in Fig. 4. Cells were treated with ZnO-NPs and HETC at different concentrations ranging from 10 to $50 \mu \mathrm{g} / \mathrm{ml}$, and then, the percentage of cytotoxicity was analyzed. The $\mathrm{IC}_{50}$ value was found to be $23.13 \mu \mathrm{g} / \mathrm{ml}$ for $\mathrm{ZnO}-\mathrm{NPs}$ and $37.13 \mu \mathrm{g} / \mathrm{ml}$ for HETC. The result emphasized that ZnO-NPs showed maximum concentration-dependent cytotoxicity to DLA cells when compared with the hydroethanolic extract. Our results are in good accordance with Sriram et al. [1] who reported that the AgNPs also showed dose-dependent cytotoxicity against DLA cells.

Determination of cytotoxicity by trypan blue dye exclusion assay Cytotoxic activity of ZnO-NPs and HETC on DLA cells was assessed by Trypan blue dye exclusion method. Fig. 5 represents the percentage cytotoxicity of the DLA cells at different concentrations of ZnO-NPs and HETC ranging from 10 to $50 \mu \mathrm{g} / \mathrm{ml}$. The sample showed the viable cells which remained unstained by trypan blue and were counted with the use of a hemocytometer. The $\mathrm{IC}_{50}$ of the ZnO-NPs and HETC was found to be $25.81 \mu \mathrm{g} / \mathrm{ml}$ and $38.78 \mu \mathrm{g} / \mathrm{ml}$ on DLA cell lines. When compared with the hydroethanolic extract, ZnO-NPs exhibited maximum cytotoxicity in a dose-dependent manner. Khairunnisa and Karthik [15] also reported that Hymenodictyon excelsum bark extract was found to have cytotoxic effects against DLA cells which further supported our study.

\section{DNA ladder assay}

The antitumor activity was further confirmed by DNA ladder assay which is an indicator of late apoptosis [2]. Fig. 6 revealed the electrophoretic pattern of the DNA fragmentation assay. In DLA control group (Lane 2), DNA fragmentation ladders were not observed while minimum fragmentation was noticed in HETCtreated group (Lane 3 at $50 \mu \mathrm{g} / \mathrm{ml}$ concentration). The group treated with standard drug and $\mathrm{ZnO}-\mathrm{NPs}(50 \mu \mathrm{g} / \mathrm{ml})$ exhibited extensive double-strand breaks, thereby yielding a ladder appearance which confirmed apoptosis. The 100 bp ladder (Lane 1) served as a marker. This implied that $\mathrm{ZnO}$-NPs possess maximum apoptotic inducing effect by causing DNA damage to DLA cells when compared with hydroethanolic extract. Our results are in good rapport with the work done by Sriram et al. [1] who reported that AgNPs induced a apoptosis by cellular DNA fragmentation.

Detection of apoptotic morphological changes by AO/EB dual staining method

To confirm whether the cytotoxic effect is induced by ZnO-NPs and HETC involve apoptosis, morphological changes in the nanoparticletreated and untreated cells were observed through AO/EB dual staining method (Fig. 7). AO is a cationic dye that enters only live cells and stain DNA, and hence, the live cells were observed as green under blue emission. On the contrary, ethidium bromide stains DNA in the cells undergoing apoptosis, and hence, apoptotic cells appeared orange in color [16]. Untreated (DLA control) cells emitted green fluorescence indicating normal nucleus with intact cell membrane. The HETCtreated cells emitted green fluorescence which might be due to the

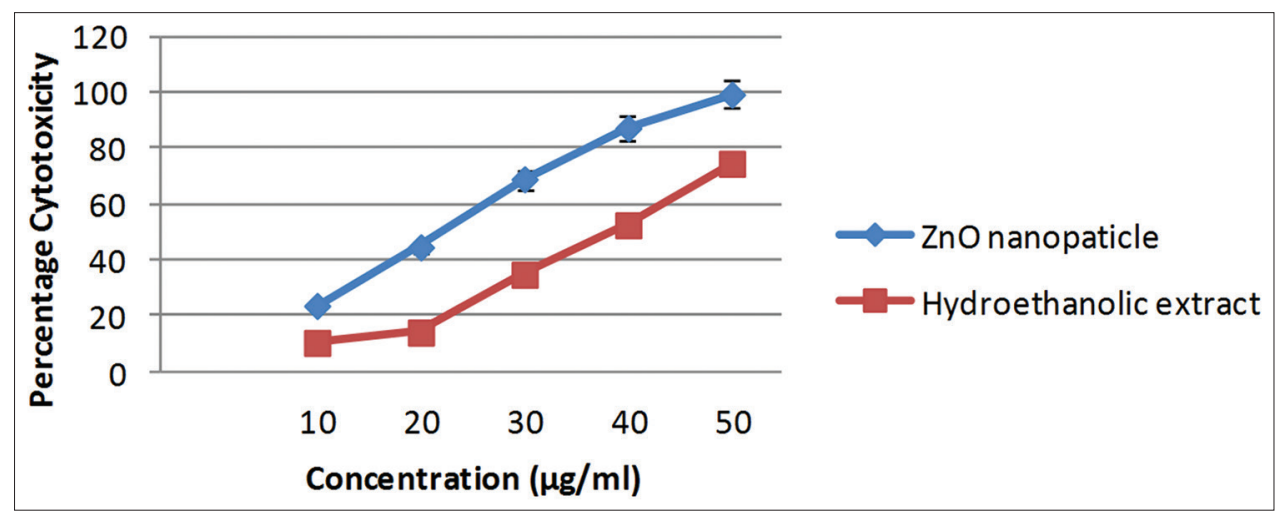

Fig. 4: Determination of percentage cytotoxicity using 3-(4,5-dimethythiazol-2-yl)-2,5-diphenyltetrazolium bromide assay. Values were expressed as mean \pm standard deviation for triplicates

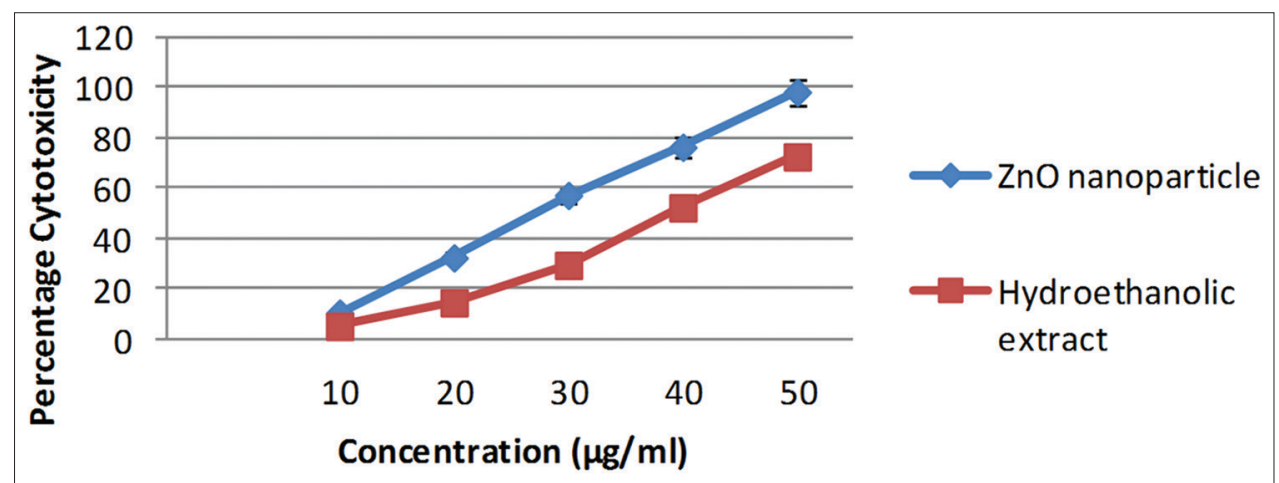

Fig. 5: Determination of percentage cytotoxicity using trypan blue dye exclusion assay. Values were expressed as mean \pm standard deviation for triplicates 


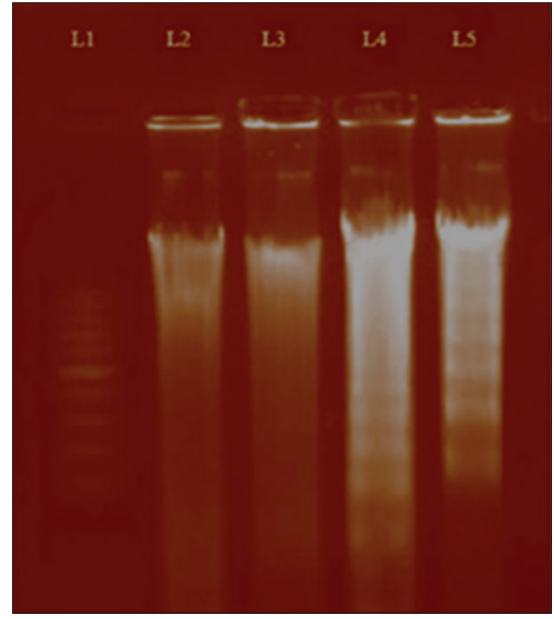

Fig. 6: Determination of antitumor activity by DNA ladder assay. Lane 1: 100 bp DNA marker; Lane 2: Dalton's lymphoma ascites (DLA) cell line (untreated); Lane 3: DLA cell line treated with hydroethanolic extract of Turbinaria conoides $(50 \mu \mathrm{g} / \mathrm{ml})$; Lane 4: DLA cell line treated with zinc oxide nanoparticles (50 $\mu \mathrm{g} / \mathrm{ml}) ;$ Lane 5: DLA cell line treated with doxorubicin $(10 \mu \mathrm{g} / \mathrm{ml})$
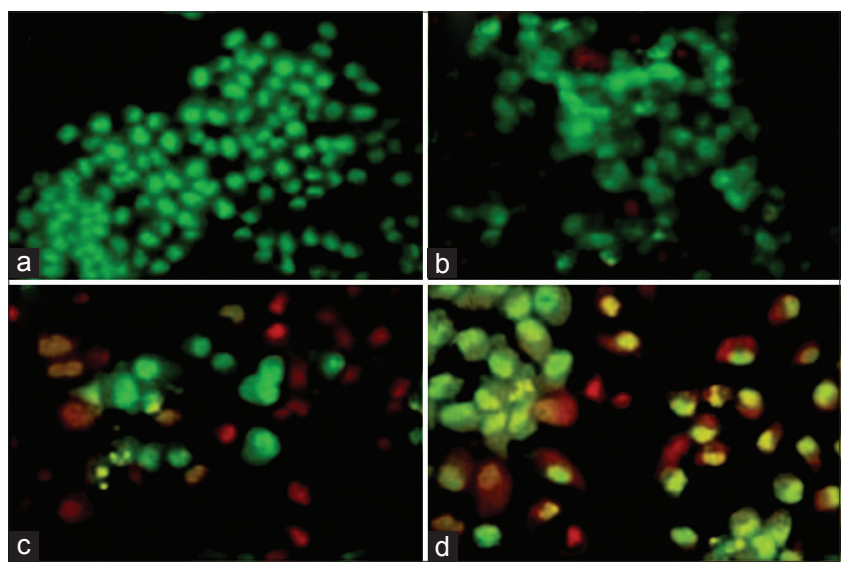

Fig. 7: Effect of zinc oxide nanoparticles (ZnO-NPs) on apoptotic morphological changes in Dalton's lymphoma ascites (DLA) cells. (a) DLA cell line (control); (b) DLA cell line treated with HETC (50 $\mu \mathrm{g} / \mathrm{ml}$ ); (c) DLA cell line treated with ZnO-NPs (50 $\mu \mathrm{g} / \mathrm{ml}) ;(d)$

DLA cell line treated with 5-fluorouracil $(10 \mu \mathrm{g} / \mathrm{ml})$

permeabilization of a cytoplasmic stain that stained the viable cells. The $\mathrm{ZnO}$-NPs-treated cells exhibited reddish-orange fluorescence indicating the loss of membrane integrity, cellular shrinkage, membrane blebbing, and typical nuclear fragmentation which might be due to apoptosis, and the results were also compared with to that of the standard. The findings revealed that the HETC exhibited minimum apoptotic inducing effect when compared to ZnO-NPs. Our study was in accordance with the work done by Antony et al. [2] who also reported that the AgNPs derived from Ficus religiosa induced apoptosis and morphological changes in DLA cells.

\section{CONCLUSION}

Our findings clearly demonstrated that exposure of Dalton's lymphoma cells to the biosynthesized $\mathrm{ZnO}$-NPs exhibited the maximum cytotoxic and apoptotic inducing effects when compared with the hydroethanolic extract of T. conoides. The results are found to be promising and are further required to elucidate the detailed molecular mechanism regulated by the ZnO-NPs to combat cancer.

\section{CONFLICTS OF INTERESTS}

Declared none.

\section{REFERENCES}

1. Sriram MI, Kanth SB, Kalishwaralal K, Gurunathan S. Antitumor activity of silver nanoparticles in Dalton's lymphoma ascites tumor model. Int J Nanomed 2010;5:753-62.

2. Antony JJ, Sithika MA, Joseph TA, Suriyakalaa U, Sankarganesh A, Siva D. In vivo antitumor activity of biosynthesized silver nanoparticles using Ficus religiosa as a nanofactory in DAL induced mice model. Colloids Surf B 2013;108:185-90.

3. Kawadkar J, Chauhan MK, Maharana M. Nanobiotechnology: Application of nanotechnology in diagnosis, drug discovery and drug development. Asian J Pharm Clin Res 2011;4:23-8.

4. Kalaiselvi M, Narmadha R, Ragavendran P, Ravikumar G, Gomathi D, Sophia $\mathrm{D}$, et al. In vivo and in vitro antitumor activity of Jasminum sambac (Linn) ait Oleaceae flower against Dalton's ascites lymphoma induced Swiss Albino mice. Int J Pharm Pharm Sci 2012;4:144-7.

5. Krishnaveni M, Mirunalini S. Amla-the role of ayurvedic therapeutic herb in cancer. Asian J Pharm Clin Res 2011;4:13-7.

6. Venkatalakshmi P, Brindha P, Induja K. In vitro antioxidant and antitumor studies on Terminalia catapa bark. Int J Pharm Pharm Sci 2014;6:1-3.

7. Sharma R, Chandan G, Chahal A, Saini RV. Antioxidant and anticancer activity of methanolic extract from Stephania elegans. Int J Pharm Pharm Sci 2017;9:245-9.

8. Abirami RG, Kowsalya S. Anticancer activity of methanolic and aqueous extract of Ulva fasciata in albino mice. Int J Pharm Pharm Sci $2012 ; 4: 681-4$

9. Mosmann T. Rapid colorimetric assay for cellular growth and survival: Application to proliferation and cytotoxicity assays. J Immunol Methods 1983;65:55-63.

10. Kuttan R, Bhanumathy P, Nirmala K, George MC. Possible anticancer activity of turmeric. Cancer Lett 1985;29:197-202.

11. Lin J, Wu YJ, Yang DJ, Zhao YQ. Effect of apogossypolone on induction apoptosis in multiple myeloma cells and its mechanisms. J Exp Hematol 2009;17:92-8

12. Anter J, Bedmar Z, Pulido M. A pilot study on the DNA-protective, cytotoxic, and apoptosis-inducing properties of olive-leaf extracts. Mutat Res 2011;723:165-70.

13. Imitan S, Albonetti S, Forni L, Peri F, Lazzari D. Solvothermal Synthesis and properties control of doped $\mathrm{ZnO}$ nanoparticles. J Coll Interface Sci 2009;329:73-80.

14. Ochieng PE, Iwuoha E, Michira I, Masikini M, Ondiek J, Githira P, et al. Green route synthesis and characterization of $\mathrm{ZnO}$ nanoparticles using Spathodea campanulata. Int J Biochem Phys 2015;23:53-61.

15. Khairunnisa K, Karthik D. Evaluation of in vitro apoptosis induction, cytotoxic activity of Hymenodictyon excelsum (Roxb) Wall in Dalton's lymphoma ascites (DLA) and lung fibroblast-mouse L929 cell lines. J Appl Pharm Sci 2014;4:11-7.

16. Sridevi M, John B, Yamini K. Anti-cancer effect of Ocimum sanctum ethanolic extract in non-small cell lung carcinoma cell line. Int J Pharm Pharm Sci 2016;8:242-6. 